$$
\text { JOES } \begin{aligned}
& \begin{array}{l}
\text { Journal } \\
\text { of Educational } \\
\text { Study }
\end{array} \\
& \text { Study }
\end{aligned}
$$

ISSN 2798-0650

Volume 1 Issue 22021

DOI: $10.36663 /$ joes.v1i2.150

\title{
The Use of Powtoon as Media to Enhance EFL Students' English Skill
}

Putu Yuliantini, Ganesha University of Education, Indonesia putuyuliantini1999@gmail.com

\begin{abstract}
The title of this research was "The Use of Powtoon as Media to Enhance EFL students' English Skill". This study aims to explain that the use of Powtoon as media could enhance EFL students' English skill such as listening, speaking, reading, writing and the benefit of Powtoon as learning media. Technology was growing fast. However, the teacher was still could not adapt to technology in the teaching and learning process. Therefore, the lack of good learning media makes students found some difficulties in understanding the material. The research design used the library research method that collected data from some articles, journals, books, and library resources. Based on the findings, Powtoon could be a solution to enhance EFL students' English skills to have good communication skill in the learning process. Powtoon has many beneficial features such text, music, animation, characters, and audio-visual for EFL students in enhancing their English skills, such as listening, speaking, reading, and writing.
\end{abstract}

Keywords: Learning media, EFL students, Powtoon

\section{Introduction}

English is an international language that makes all of the countries should learn English. People use English to establish communication in business, commerce, education, politics, industry, and other professions in the International event (Syafitri et al., 2018). Therefore, English is one of the subjects in the education curriculum of Indonesia, which has to be taught from elementary school until university. However, many students in Indonesia still face difficulties in learning English. In English the written and spoken form is different. Therefore, Indonesian students called EFL students because they learn English as a Foreign Language. EFL students find learning English challenging and need motivation in understanding the material (Binnur, 2009). Besides, EFL students also find that the method, technique, and media was monotonous. Thus, technology is growing fast, the teacher and students should adapt to the technology. In this era, ICT (Information and Communication Technology) becomes the revolution of learning to have a good curriculum (Raman \& Yamat, 2014). There are several 


\section{JOES $\begin{aligned} & \begin{array}{l}\text { Journal } \\ \text { of Educational } \\ \text { Study }\end{array}\end{aligned}$}

ISSN 2798-0650

Volume 1 Issue 22021

DOI: $10.36663 /$ joes.v1i2.150

types of ICT, namely computer, laptop, radio, and telephone. In this case, using ICT gives students a chance to interact with others in a real-life situation and use other languages instead of their mother language (Semaan, 2018).

According to Talebian et al. (2014), there are several advantages of using ICT in the learning process. First, it is flexible, which means that students can access ICT everywhere and anytime within the due date, and every student has the same chance to access the learning. Second, it can train the students' collaborative skill. In this case, students can be connected via chat, voice, conferences, and video call to share their opinion. Third, ICT provide attractive teaching and learning process. Hence, it built students' motivation in the learning process. Meanwhile, there are some disadvantages of ICT in the learning process (Talebian et al., 2014). First, ICT needs a good internet connection. In this case, not all of the students have a good internet connection in their area. Second, some teachers still cannot design the ICT teaching and learning process. Therefore, the teacher cannot provide engaging learning for students. Thus, ICT is a helpful tool for students that can use in the learning process, such as media internetbased.

Moreover, media plays an important role in the learning process. Media contribute to the learning process as it can increase students' ability (Syafitri et al., 2018). Besides, media is also used as a solution to stimulate students' feelings in the learning process. The use of learning media is to achieve the learning objectives and students' improvement in the learning process (Marpanaji et al., 2018). In this case, teaching students should begin from the simplest to the most complex one to avoid students' stress. Furthermore, the use of learning media for teaching EFL students is needed. According to Arsyad Azhar (2002), as cited in (Harahap \& Siregar, 2018), there are some benefits of using learning media in the learning process. First, learning media can increase students' motivation in the learning process because some learning media have many features that engage students' attention, such as pictures, music, animation, or video. Second, using learning media show a positive impact on the students' achievement in the learning process. Students will pleasantly understand the learning material. Third, the use of learning media makes learning flexible and efficient. In this case, the teacher needs to prepare attractive media to explain the material. It will be easier for the teacher in preparing the material. There are two types of media, namely traditional and digital media. Teachers commonly use traditional media such as flashcards, dolls, puzzles, and toys to teach English. It becomes difficult for the teacher to use digital media because it is not familiar to them. Video, song, and recording are examples of digital media. In explaining the material, the teacher can use appropriate media to make the students easier to understand the material. Hence, an appropriate learning media should contain pictures, music, text, audio of how to pronounce the word, vocabulary that is easy to remember, and an internet-based that is accessible for EFL students (Khalidiyah, 2015 as cited in (Ling. L, 2009). Therefore, it makes EFL students' English skill improved during the time. 


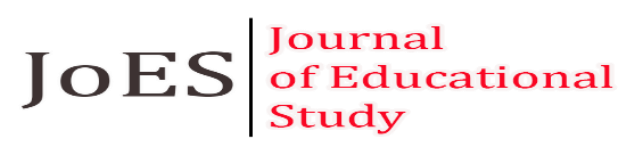

ISSN 2798-0650

Volume 1 Issue 22021

DOI: 10.36663/joes.v1i2.150

One of the alternative digital media that can be used to teach EFL students is Powtoon. Powtoon can help the teacher in designing the learning process. By using Powtoon, the teacher can design attractive and enjoyable learning. According to Semaan (2018). Powtoon is a webbased tool that has various features such as cartoons, graphics, animation, and pictures. It can be used as an animated presentation in the learning process to become interesting for the students. The teacher can make or find out Powtoon based on students' need and syllabus. Powtoon is a web-based application similar to PowerPoint, Prezi and Impress because it uses slides in developing the material. Also, the font and animation in Powtoon can engage students' attention (Sutisna et al., 2019). Besides, Powtoon is an audiovisual media to engage students' attention through audio and visualization (Yuniari, 2018). Thus, it can be concluded that Powtoon is an application that can help the teacher prepare material, and its features can attract students' attention.

Many researchers have studied Powtoon to enhance English skill. Tanjung (2020) conducted research entitled "Technology Integration in EFL Teaching and Learning in Indonesia using Powtoon". This study was using a qualitative method, and the data were collected by using observation and interviews. The research had the purpose of developing technology-based learning by using Powtoon as the media of learning English. Based on the result, by using Powtoon, students could utilize the technology. Powtoon built students' creativity and developed their ideas in collaboration. Powtoon could be used to teach four English skills such as listening, speaking, reading, and writing. Moreover, Powtoon could enhance EFL students' interest to learn English, especially in Indonesia.

Furthermore, Purnamasari \& Maolida (2018) conducted a study entitled "Students' Voice on the Use of Powtoon as a Tool to Optimize Their Skills in Designing Presentation". The study was designed qualitatively, and the data collection was using observation, students' interviews, and questionnaires. The purpose of this research was to investigate the implementation of Powtoon in designing presentations, students' responses toward the implementation of Powtoon, and the challenges that the students found during the process. The researchers found that the implementation of Powtoon showed various responses from students. It could be seen from the questionnaires that students gave a positive response towards the Powtoon. Powtoon has successfully created engaging learning as it consisted of music, animation, and cartoon. By using Powtoon, students could develop their creativity in designing their presentation. Mostly, students were not familiar with Powtoon and internet connection. It became challenging for them in designing the presentation. It was suggested to guide, monitor, and give correction and evaluation for students in implementing Powtoon to design presentations for the teacher.

Semaan (2018) conducted research entitled "The Effect of Using Powtoon on Learning English as a Foreign Language". The purpose of this research was to investigate the effectiveness of using Powtoon in the EFL classroom. The selected sample was nine candidates based on students' achievement levels in English, such as three high-achievers, four average students, and 


\section{JOES $\mid \begin{aligned} & \text { Journal } \\ & \text { of Educational } \\ & \text { Study }\end{aligned}$}

ISSN 2798-0650

Volume 1 Issue 22021

DOI: $10.36663 /$ joes.v1i2.150

two low-achievers. The research was using students' interviews, teacher's post-interview, and students' observation as instruments. Based on the result, there were positive impacts of using Powtoon for students, such as improving students' engagement, language acquisition, new experience, and better comprehension. Also, the implementation of Powtoon built the students' enthusiasm in the learning process through collaboration. Therefore, the teacher showed their interest in using Powtoon in the learning process.

Based on those previous study showed learning media is needed to use in learning English. It was because EFL students need to mastery English skill in order to communicate with foreigners or in the field of education. Thus, using Powtoon to teach EFL students could help them in practising their English skill correctly. Therefore, this study aimed to explain that the use of Powtoon as media could enhance EFL students' English skill such as listening, speaking, reading, writing and benefit of Powtoon as learning media.

\section{Method}

The research design was using the library research method. According to Zeid (2004), library research collects data from some articles, journals, books, and library resources. Hence, the collection of library research by reading, recording and processing research data. In this case, the activity was done in the library collection without going the field research. The instrument was analyzed literature review or content analysis research, and it was described qualitatively. It aims to collect some data from the previous study that relate and support the validity of this research.

The data have collected to support the statement that Powtoon as media could improve EFL students' English skill. The theories used from various articles, journals and books that related to the topic in this study. The articles and journals are used to strengthen the data about the benefits of using Powtoon as media to enhance EFL students' English. There are some steps to start this research, such as collecting some sources, reading various sources, classifying the data, analysing the data to answer the purpose of the research in the form of descriptive findings and discussion.

\section{Findings}

Many researcher found that Powtoon as media could improve EFL students' English skill and their motivation in the learning process. Bharu et al. (2018) argued provide the appropriate teaching and learning method for reading skills, assess students' perception towards the use of Powtoon, and evaluate students' intention towards using a mobile phone for the flipped classroom. The data were collected through questionnaires and descriptive analysis. The result showed that Powtoon completed students' needs in the learning process. Powtoon video had many features for better learning, such as the organization of the text, including the font, text 


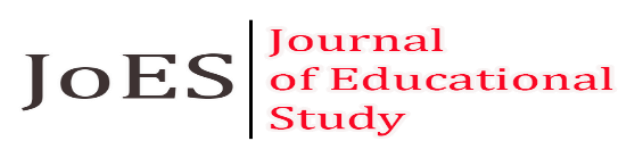

ISSN 2798-0650

Volume 1 Issue 22021

DOI: 10.36663/joes.v1i2.150

length, colour, animation, content, and the explanation on the video. The flipped classroom was also supported by mobile phones in the learning process that made it students easier to access the learning. On the other hand, Yuniari (2018) state that student's achievement in the learning process with Powtoon audiovisual media was better than in conventional learning. Based on the score, the mean score showed the experimental group was 75.18, and the mean score of conventional was 66.00. The result of the t-test showed that there was a significant improvement in students' achievement in writing. Therefore, the use of Powtoon audiovisual media was recommended for teaching students in English. Furthermore, Sutisna et al. (2019) found that Powtoon software in narrative text learning could help the students understand the material. Also, the use of Powtoon software made learning more enjoyable. Furthermore, two things had to be considered, such as animated motion due to its distraction towards the students' concentration in understanding the material and the speed of the video that should not be too fast or too slow because students should focus on the material.

Moreover, Adnyani et al. (2020) argued to develop digital learning media for young learners by using Powtoon. There were five stages that should conduct namely Analyze, Design, Development, Implementation, and Evaluation (ADDIE). In the first stage, the researchers investigated young learners, specifically the elementary students from first until sixth grade, chosen as the target group. In the second stage, the topic and blueprint were designed in which the blueprint consisted of grade, competence-based, the learning topic, activities, list of vocabulary, and script. In the third stage, the blueprint was developed into Powtoon based-video media. In the fourth stage, Powtoon based-video media was implemented at the school. After watching the video, the teacher and students were given questionnaires and interviews about their responsibility towards the Powtoon based-video media. In the last stage, it showed students' responses towards the Powtoon based-video media. The teacher also gave a response to the affectivity of Powtoon based-video media in the learning process. The result showed a positive impact of using Powtoon as attractive in the learning process. Therefore, the use of Powtoon as learning media was recommended. However, the teacher must prepare another attractive learning medium besides watching the video.

Therefore, it showed that Powtoon could help students improve EFL students' English skills such as listening, speaking, reading, and writing. Besides, Pais et al. (2017) have some advantages of using Powtoon as learning media. First, Powtoon is interactive. It is because Powtoon can increase students' motivation in the learning process. Second, Powtoon has many features such as text, font, animation, and music that can engage students' attention in the learning process. Third, Powtoon can teach a small or big group that makes students focus on the learning process. Fourth, Powtoon can increase students' skills in English. Therefore, students can practice their English skill by using Powtoon as media. The last, by using Powtoon, students can have a better understanding of the material. Hence, the use of Powtoon can increase students' achievement in the learning process. 


\section{JOES $\begin{aligned} & \begin{array}{l}\text { Journal } \\ \text { of Educational } \\ \text { Study }\end{array} \\ & \text { Studion }\end{aligned}$}

ISSN 2798-0650

Volume 1 Issue 22021

DOI: $10.36663 /$ joes.v1i2.150

\section{Discussions}

EFL (English as a Foreign Language) is used to describe English by non-native speakers that English is not dominant. In this case, EFL students have introduced to their first language or mother tongue before learning English (Ratminingsih, 2019). For example, in Indonesia, Indonesian have known their mother tongue since they were born and used it to communicate in daily life. In addition, EFL students ha the purpose to learn English, such as communicating with foreigners or in the context of education and EFL students less exposure to English outside English class. Brown (2001) state EFL students have limited chance to practice communicate using English outside the classroom. According to Ratminingsih (2019), there were guidelines that EFL students should do in order to have a chance to practising English. First, EFL students use the time in the English class properly and do the interaction well. Second, EFL students do not waste time in the English class by doing the assignment. Third, the teacher should prepare activities that could stimulate and motivate students in learning English. Fourth, the teacher should facilitate students learning English based on the real-life situation or daily life. Fifth, the teacher should decrease the test and more focus on the use of language in communication. Sixth, the teacher provides extra fun learning English such as watching English movies, listening to the English TV or radio, asked students to find a partner to practice their speaking skill, training students' reading skill outside the classroom by reading a book, newspaper, magazine, and asked students do journaling or dairy while learning English in order to improve students' writing skill. Besides, Brown (2001) argue that EFL students use some sources to practice English, such as a book, club English, private English, and YouTube videos. Therefore, EFL students need several media that could help in improving their English skill.

Learning media is an instrument or tool that can help teachers deliver the material and make students understand the learning easily (Sahronih et al., 2019). Learning media has many types, such as pictures, audio, or video. In learning media, technology is as an essential role in creating attractive and innovative media. Besides Puspitarini et al. (2019), learning media is a tool used to know students' response, attention, and motivation that supports the learning process. It can be used to communicate the messages on the material in the form of contextual and textual. The use of ICT (Information Communication and Technology) in the teaching and learning process is growing fast. Semaan (2018) argued ICT (Information Communication Technology) plays an essential role in education. Hence, ICT is needed to support the learning process. Technology based-video is helpful for students in the learning process because it increases students' motivation in the learning process. The development of technology in education can help the teacher in designing the material and attractive learning media. The use of ICT gives a chance for the students to interact with others in real-life situations and use other languages instead of their mother language (Ghasemi \& Hashemi, 2011). In ICT, applying email, blogs, or attractive videos to support the learning process lets students develop their creativity 


\section{JOES $\begin{aligned} & \begin{array}{l}\text { Journal } \\ \text { of Educational } \\ \text { Study }\end{array}\end{aligned}$}

ISSN 2798-0650

Volume 1 Issue 22021

DOI: $10.36663 /$ joes.v1i2.150

and build students' curiosity. Many digital media are designing based on student's level and learning objectives to help students understand the material (Lieberman et al., 2009). Digital media is arranged in the attractive video, audio recording, and music that help students learn English. Using digital media can improve students' vocabulary mastery, listening, writing, reading, and speaking skills through internet-based animated videos and books during online learning. Besides, the use of digital media can build students' creativity and motivation in the learning process. In this case, digital media that could help EFL students in improving English skill is Powtoon.

Heryanto \& Rahayu (2021) conducted research entitled The Influence of Powtoon Media in Teaching Listening. Regarding the 2013 curriculum, the use of technology in learning English became popular. The teacher was forced to adapt to the technology. This research aimed to the influence of Powtoon media in teaching listening. Hence, the interaction between the teacher and students should be built at the beginning of class to make it more accessible in giving and receiving the information. Students should train to become good listeners in daily life. In this case, listening skill is an English skill that must be mastery because it is used to communicate in the English class or global business. Students face some problems in the learning process, such as choosing the word, how to pronounce the word, and challenging to elaborate idea in writing. In this case, the lack of students' vocabulary mastery makes it challenging to understand the word. It is because the written form is different from speaking. Thus, the teacher suggested using Powtoon in teaching English. Powtoon has features that could support the learning to make students not bored in the learning process. The use of Powtoon also builds students' motivation and participation during the learning process. Based on the percentage, most students agree that the use of Powtoon media in teaching listening could influence students to get a good score. In this case, Powtoon media could help students became active learners and understanding the material well.

Besides, the use of Powtoon as media also could improve students' speaking skill (Syafitri et al., 2018). Speaking is one of the English skill that important in doing communication and some activities in speaking such as process producing, receiving, and processing the information. Those activities aimed to get ideas, opinion, and feelings. Nevertheless, some students thought that speaking was not accessible. In this case, students find difficulties in producing, receiving, and processing information. The reason was that the written form, different from the spoken form, did not know how to pronounce the word. Moreover, students were afraid to make mistakes and afraid that the teacher or their friends could not understand. In addition, the teacher needs to prepare media that could facilitate students to train their speaking skill, especially their pronunciation. By looking at those problems, Powtoon media could be a solution to teach speaking skill. The use of visual learning media made students more enjoy the learning and became more effective. Two guidelines could help students process and understand the 


\section{JOES $\mid \begin{aligned} & \text { Journal } \\ & \text { of Educational } \\ & \text { Study }\end{aligned}$}

ISSN 2798-0650

Volume 1 Issue 22021

DOI: $10.36663 /$ joes.v1i2.150

information, and first, explaining clearly the objectives of each part of the animation. In this case, Powtoon contains music, song, video, audio and visual instruction. However, the students were still the teacher's guidance during the learning process. It suggested that the teacher guide the students by using a simple question that could check students' understanding of the material. Second, using the interactive features provided in the Powtoon. It means that using Powtoon could help students to prepare their pronunciation before they were speaking. Based on this research, the interactive video makes the learning became efficient. In this case, the teacher provides a video containing simple explanations and questions arranged in an exciting video. The teacher a facilitator and guide in the learning process by giving enough time for students to answer the question. Besides, the teacher could pause the video and support students to build their confidence in speaking. On the other hand, the use of Powtoon as media in teaching speaking skill also improve students' motivation in the learning process. In this case, students could learn English in exciting activities and give a chance to discuss, respond, and practice dialogue well. Furthermore, students became active learners.

Oktaviani \& Mandasari (2020) state that teaching reading by using multimedia allows them to visualize and feel like experiencing it directly because of the multimedia features. In this case, cultural learning should be given in the classroom because it supports language learning. People who speak the target language may not communicate well if they do not know what or when to use expressions if they do not understand the culture. One of the supporting media that could use to teach Basic Reading Class was Powtoon. The features of Powtoon that could categorize the presentation based on the education, business, economic, and the other. Furthermore, Powtoon contains text, music, and animation that interested in reading the presentation. The use of Powtoon could increase students' ability to learn the language. Students could also create a cultural presentation in an attractive way supported by many features in Powtoon. Besides, it could build students' creativity and improve their ability in using technology. Therefore, the use of Powtoon could improve students' engagement in the Basic Reading class. Anita \& Kardena (2021) argue That Powtoon as a medium can increase student motivation in writing based on the results of the analysis. Using suitable media such as Powtoon, students' awareness to pay more attention to the lesson becomes better. Some students who want teachers to use media in teaching writing have realized its effect on their motivation for lessons. Moreover, make students understand the lesson effectively and efficiently. In addition, teachers as facilitators are advised to provide appropriate media such as Powtoon. Powtoon also helps students in understanding the material by watching Powtoon and increases students' motivation in learning. In this case, students also need to practice a lot to improve their writing skills.

Therefore, Powtoon is an animated based video that can as media. Powtoon has many features that beneficial to help EFL students learning English. The lack of appropriate media in the learning process makes students found some difficulties in understanding the material. The 


\section{JOES $\begin{aligned} & \begin{array}{l}\text { Journal } \\ \text { of Educational } \\ \text { Study }\end{array} \\ & \text { Studionat }\end{aligned}$}

ISSN 2798-0650

Volume 1 Issue 22021

DOI: $10.36663 /$ joes.v1i2.150

teacher can provide students with a good learning media that is Powtoon. Therefore, the use of Powtoon can be a solution to teach EFL students in order to improve their English skill in the learning process.

\section{Conclusions and Suggestions}

This research aimed to explain that the use of Powtoon as media could enhance EFL students' English skill such as listening, speaking, reading, writing and the benefit of Powtoon as learning media. The result showed Powtoon as media could improve students English skill such as listening, speaking, reading and writing. Many features supported it in the Powtoon, namely music, audio, animation, text and character, that can create the enjoyment of learning in the EFL classroom, increase students' motivation and fulfil students' needs in learning English. To avoid students stress in the learning process, the teacher needs to prepare a good learning process that required students to practice their English skill by using Powtoon as media is a good choice to improve EFL students' English skill. Besides, Powtoon has many benefits in learning English. First, Powtoon is interactive. Second, Powtoon has many features such as text, font, animation, and music that can engage students' attention in the learning process. Third, Powtoon can teach a small or big group that makes students focus on the learning process. Fourth, Powtoon can increase students' skills in English. It recommended for the teacher to provides learning media that could facilitate EFL students in enhancing their English.

\section{References}

Adnyani, L. D. S., Mahayanti, N. W. S., \& Suprianti, G. A. . (2020). PowToon-Based Video Media for Teaching English for Young Learners: An Example of Design and Development Research. 394(January 2012), 221-226. https://doi.org/10.2991/assehr.k.200115.036

Anita, A. S., \& Kardena, A. (2021). the Effect of Using Powtoon Toward Students 'Motivation in Writing. 6(1), 1-13.

Bharu, K., Kelantan, M., Ainul, S., Ayub, A., Nazihah, W., Mohamed, W., Ain, N., Malek, A., Kamarudin, H., Pengajian Bahasa, A., Teknologi, U., \& Kelantan, M. C. (2018). Contextual Clues PowToon for Flipped Classroom. Kelantan International Learning and Innovation Exhibition, 2018(August), 16-21. http://ir.uitm.edu.my/id/eprint/24810/

Ghasemi, B., \& Hashemi, M. (2011). ICT: Newwave in English language learning/teaching. Procedia - Social and Behavioral Sciences, 15, 3098-3102. https://doi.org/10.1016/j.sbspro.2011.04.252

Harahap, M., \& Siregar, L. M. (2018). Mengembangkan Sumber dan Media Pembelajaran. Educational, January, 2-3. https://doi.org/10.13140/RG.2.2.19282.86721

Heryanto, G., \& Rahayu, S. (2021). the Influence of Powtoon Media in Teaching Listening. PROJECT (Professional Journal of English Education), 4(1), 86. https://doi.org/10.22460/project.v4i1.p86-90

Lieberman, D. A., Bates, C. H., \& So, J. (2009). Young children's learning with digital media. 


\section{JOES $\begin{aligned} & \begin{array}{l}\text { Journal } \\ \text { of Educational } \\ \text { Study }\end{array}\end{aligned}$}

ISSN 2798-0650

Volume 1 Issue 22021

DOI: $10.36663 /$ joes.v1i2.150

Computers in the Schools, 26(4), 271-283. https://doi.org/10.1080/07380560903360194

Ling. L. (2009). On the Use of Films in EFL Classroom. US-China Foreign Language Journal, $7(12), 18-21$.

Marpanaji, E., Mahali, M. I., \& Putra, R. A. S. (2018). Survey on How to Select and Develop Learning Media Conducted by Teacher Professional Education Participants. Journal of Physics: Conference Series, 1140(1). https://doi.org/10.1088/1742-6596/1140/1/012014

Oktaviani, L., \& Mandasari, B. (2020). Powtoon: A Digital Medium to Optimize Students' Cultural Presentation in ELT Classroom. Teknosastik, 18(1), 33. https://doi.org/10.33365/ts.v18i1.526

Pais, M. H. R., Nogués, F. P., \& Muñoz, B. R. (2017). Incorporating powtoon as a learning activity into a course on technological innovations as didactic resources for pedagogy programs. International Journal of Emerging Technologies in Learning, 12(6), 120-131. https://doi.org/10.3991/ijet.v12i06.7025

Purnamasari, Y., \& Maolida, E. H. (2018). Students' Voices on the Use of Powtoon as a Tool to Optimize Their Skills in Designing Presentation. January 2017, 410-413. https://doi.org/10.5220/0007168204100413

Puspitarini, Y. D., Akhyar, M., \& . D. (2019). Development of Video Media Based on Powtoon in Social Sciences. International Journal of Educational Research Review, 198-205. https://doi.org/10.24331/ijere.518054

Raman, K., \& Yamat, H. (2014). Barriers Teachers Face in Integrating ICT during English Lessons: A Case Study. Malaysian Online Journal of Educational Technology, 2(3), 11-19.

Sahronih, S., Purwanto, A., \& Sumantri, M. S. (2019). The effect of interactive learning media on students' science learning outcomes. ACM International Conference Proceeding Series, Part F1483(July), 20-24. https://doi.org/10.1145/3323771.3323797

Semaan, C. (2018). Research Article The Effect Of Using Powtoon Pow Oon On Learning English As A Foreign Language * Charbel Charbel Semaan and Nour Ismail. International Journal of Current Research, 10(5), 69262-69265.

Sutisna, E., Vonti, L. H., \& Tresnady, S. A. (2019). the Use of Powtoon Software Program in Teaching and Learning Process: the Students' Perception and Challenges. Jhss (Journal of Humanities and Social Studies), 3(2), 81-85. https://doi.org/10.33751/jhss.v3i2.1461

Syafitri, A., Asib, A., \& Sumardi, S. (2018). An Application of Powtoon as a Digital Medium: Enhancing Students' Pronunciation in Speaking. International Journal of Multicultural and Multireligious Understanding, 5(2), 295. https://doi.org/10.18415/ijmmu.v5i2.359

Talebian, S., Mohammadi, H. M., \& Rezvanfar, A. (2014). Information and Communication Technology (ICT) in Higher Education: Advantages, Disadvantages, Conveniences and Limitations of Applying E-learning to Agricultural Students in Iran. Procedia - Social and Behavioral Sciences, 152, 300-305. https://doi.org/10.1016/j.sbspro.2014.09.199

Tanjung, L. A. (n.d.). Technology integration in EFL teaching and learning in Indonesian using PowToon. 2014.

Yuniari, N. M. (2018). The Effect of Using Powtoon Audiovisual Media Upon the Students' Writing Achievement of the Third Semester Students of English Eduacation Departement Faculty of Teacher Training and Pedagogy Dwijendra University. Widya Accarya, Vol. 9 No. http://ejournal.undwi.ac.id/index.php/widyaaccarya/article/view/668 